\title{
A Toldi tőkészletének eredetéről
}

1. A vizsgálat elözménye. Használati típusú, azaz szövegre vonatkozó (nem pedig szótári alapú) etimológiai statisztika készítésekor a vizsgálat irányulhat mind a szövegben közvetlenül megjelenő szavak eredetkategóriák szerinti arányaira, mind pedig töveiknek a származás szerinti képviseletére. Már első etimológiai statisztikám összeállításakor (HORVÁTH 2000) úgy gondoltam, hogy mindkétfajta felmérés fontos. Az akkor és később szerzett elemzési tapasztalataim arra késztettek, hogy bevezessek egy harmadik statisztikafajtát is: a lemmák eredetstatisztikáját. A lemma a szónál elvontabb egység, lényegében megfelel a lexikográfiából ismert címszónak. A lemmák eredetstatisztikájának előkészítésekor a szavakról lemetszünk bizonyos képzőfajtákat (az igenévképzőket, valamint a ható, a műveltető és a szenvedő igék képzőit), és így adunk minősítést a megmaradt szórésznek. (Részletesebben 1. HORVÁTH 2010: 426, 2017: 453.)

A Toldi etimológiai statisztikájának összeállítását néhány évvel ezelött többféle okból határoztam el. Egyrészt Arany János születése kétszázadik évfordulójának, az Arany-évnek a megünneplése ösztönzött rá. Másrészt hasznosnak, sőt szükségesnek éreztem, hogy - a korábbi statisztikák többségével ellentétben - egy teljes és terjedelmes müben mérjem fel az eredetkategóriák arányait, mégpedig olyanban, amelyet nagyon sokan ismernek és szeretnek. A Toldit abban a reményben választottam, hogy elemzésem elvei, módszerei és eredményei hasznosíthatók lesznek az oktatásban is az általános iskolától kezdve egészen a doktoranduszképzésig, persze a megfelelő szinthez igazítva. A Toldi választása mellett szólt az is, hogy előkészítésképpen nem kellett cédulázó jellegü munkát végeznem, hiszen alapanyagul rendelkezésemre állt PÁSZTOR EMIL Toldi-szótára (ToldiSz.).

Kezdettől fogva biztos voltam abban, hogy a Toldi etimológiai statisztikáját a szavakra, a lemmákra és a tövekre egyaránt kiterjedve érdemes és célszerủ elkészítenem. Ugyanakkor tisztában voltam azzal, hogy ez igencsak időigényes feladat. Természetesen arról sem feledkezhettem meg, hogy eredményeimnek legalább egy részét illő az Arany-évben közzétennem; emellett ügyelnem kellett arra, hogy ez beleférjen egy elöadásnak, illetve folyóiratcikknek a keretébe. Mindezt figyelembe véve 2017-ben úgy döntöttem, hogy a Magyar Nyelvtudományi Társaság felolvasó ülésén elhangzó előadásomban és annak írott változatában (HORVÁTH 2017) a szavak és a lemmák eredetstatisztikájának bemutatására kerítek sort. Hangsúlyoztam azonban (HORVÁTH 2017: 453, 465), hogy a tőeredet-statisztika összeállításáról és publikálásáról sem mondok le, csupán későbbre halasztom. Sajnos a halasztás különféle okokból hosszabb lett, mint reméltem. Most azonban végre bemutathatom a Toldi-beli tövek eredetstatisztikáját mint az előző tanulmány kiegészítőjét és párját.

* A tanulmány elkészítését az NKFI Új magyar etimológiai szótár. Második ütem című, K 124127. számú projektuma támogatta. (Ennek a munkálatai, amelyekben szenior kutatóként veszek részt, GERSTNER KÁROLY vezetésével folynak a Nyelvtudományi Intézetben.) Köszönöm Hoffmann Istvánnak és másik, anonim lektoromnak támogató véleményüket. 
2. A tőeredet-statisztika előkészítése. Mint a bevezetőben említettem, etimológiai statisztikámat a ToldiSz.-ra alapozva állítottam össze. Hogy az eredetstatisztika számára miféle szüréseket, átsorolásokat hajtottam végre az alapanyagon, azt az előző írásomban részletesen ismertettem (HORVÁTH 2017: 451-452), így ennek a megismétlését nem tartom szükségesnek.

A Toldiban meglévő tövek listáját a lemmáké alapján hoztam létre. A tövek megkereséséhez és eredetbeli minősítésükhöz szükség esetén az EWUng. segítségéhez fordultam.

Az összetett lemmákat elemeikre bontottam, beleértve az és, ember típusú elhomályosult összetételeket is. A származékokról levágtam a képzőt vagy képzőket, függetlenül attól, hogy tőlexémához vagy fiktív tőhöz jutok-e ezzel. Ugyanígy tettem a megszilárdult jeles vagy ragos alakulatok végződésével is. Természetesen bőven akadtak olyan esetek, amelyekben az említett műveletekből egymás után többet is el kellett végeznem. Így jutottam el például a vadmadártojás lemmától a vad, madár és tojik tövekhez, az üggyel-bajjal lemmától pedig az ügy és baj tövekhez.

Vannak olyan eredetkategóriák, amelyeknek a képviselői a közvetlen előzményükhöz képest nem tartalmaznak morfématöbbletet. Ilyen a szófajváltás és a szóhasadás.

A szófajváltás egy-két érintettje egymorfémás. Ilyen az a névelö és a de kötőszó. Ezeket a lemmákat valójában nem tőre vezetjük vissza, hanem velük azonos alakú etimológiai előzményükre: az uráli korból örökölt $a$ mutató névmásra, illetőleg az onomatopoetikus de partikulára. Ilyenkor kényszerből, terminológiai egyszerüsítésként az etimológiai előzményt a „tövek” közé sorolom, és ezt tekintem a tőeredet-statisztika részének. Jóval gyakoribb eset azonban, hogy a szófajváltás eredménye végső soron valóban morfémákra bontható. Ilyenkor a „lemma $\rightarrow$ tő" irányú átsorolást több lépcsőben, előbb nem morfológiai, majd morfológiai mủvelettel végeztem el. Például így: múlva névutó $\rightarrow$ múlva határozói igenév $\rightarrow$ múlik ige, ez pedig finnugor örökség.

A szóhasadás esetében szintén efféle altípusokkal van dolgunk. A csiny lemmának például a csín nem a töve, de erre vezethetjük vissza, így a tôstatisztikába a csín került a szláv jövevényeket képviselve. A vörös esetében viszont két lépcsöből állt a visszavezetés: előbb nem morfológiai müvelettel a véres-hez, majd a képző elhagyásával a vér-hez juthattam el, ez pedig a tövek állományában a finnugor örökség képviselője.

Az elvonással létrejött lemmákra is érvényes, hogy etimológiai előzményük hozzájuk képest nem tő, sőt magától értetődően hosszabb náluk. Ennek ellenére mint etimológiai előzményt az elvonás alapját kellett a „tövek” közé sorolnom. A vád esetében például a vádol igét, ez pedig szláv jövevény.

A belső keletkezésủ lemmák más eredetkategóriáinak reprezentánsait az imént ismertetett elvek és módszerek szerint soroltam be a tövek (illetve „tövek”) eredetkategóriáihoz.

A továbbiakban a tőeredet-statisztika szereplöit az egyszerüség kedvéért egységesen tövekként emlegetem, akkor is, ha nem morfológiai visszavezetéssel jutottam hozzájuk. 
A tövek eredet szerinti minősítéséhez - mint vizsgálatom közvetlen előzményében (HORVÁTH 2017) és más etimológiai statisztikai elemzéseimben is - az EWUng.-ot hívtam segítségül. Az EWUng. után megjelent származtatási ötleteket - a szó- és lemmastatisztika elvéhez (vö. HoRvÁTH 2017: 453) igazodva - nem vettem figyelembe.

Természetesen a kategorizálásban is alkalmazkodtam szó- és lemmavizsgálatomhoz: az alapnyelvi örökség rétegeit megkülönböztettem egymástól; nem differenciáltam a konkrétabb szóátadó nyelvek szerint az iráni, a török és a szláv jövevényeket; a valószínü eredeztetéseket pedig egyenértéküeknek tekintettem a biztosakkal.

A statisztikát ezúttal is két változatban készítettem el. Az I.-ben helyet kapott a bizonytalan és a vitatott eredetủek kategóriája. A II.-ban viszont megszüntettem őket: a bizonytalan származásúak az EWUng. szerint esetleg számításba vehető eredeztetésüknek megfelelő helyre kerültek, míg a vitatottak az EWUng.-ban első helyen szereplö minősítésüket kapták. Ehhez hasonlóan számoltam fel a II. változat számára a tisztázatlan rétegből örökölt alapnyelvi elemeknek a kategóriáját. (A két változat közötti átsorolás finomabb részleteihez l. főleg HORVÁTH 2000: 180, 321322, valamint persze a következő pontban a statisztikai táblázatok bemutatását.)

A szó- és a lemmastatisztikához hasonlóan a tőstatisztika mindkét változata tartalmaz állományi és előfordulási statisztikát. Az állo má n y i s tat i s z t i ka a tőkészlet elemeivel egy-egy egységként számol, ismétlődésüket, annak a mértékét figyelmen kívül hagyja. Az e lő fordulá s i s ta ti s z ti k a lényege viszont éppen az ismétlődés, az egyes tövek adatszáma.

3. A Toldi töveinek eredetstatisztikája. A mostani vizsgálatom korábban elkészült párja szerint a Toldi lemmaállománya 2672 tagú, összesen 9601 előfordulással (HORVÁTH 2017: 462).

Mekkora tőkészletre számíthattam ennek alapján? Számszerü becslésre nem mertem vállalkozni, hiszen a „lemmák $\rightarrow$ tövek” irányú átrendezés kétféle, egymással ellentétes következménnyel jár. Egyfelől a lemmaállományhoz viszonyítva számos új szereplő megjelenését eredményezi. Másfelől bőven akadnak olyan tövek, amelyekhez több vagy akár nagyon sok lemma gyülik össze, és ez persze az állomány elemszámának csökkenését hozza magával. Régebbi vizsgálataimban (HoRVÁTH 2000, 2010) azt tapasztalhattam, hogy a tövek állománya a szavakénál, illetve a lemmákénál jóval kisebb, előfordulási számuk összessége viszont meghaladja amazokét. Ebből kiindulva most is ilyen irányú eltérésekre számíthattam. Az eredmény igazolta ezt a feltevést, sőt nem várt mértékben: mind a tóállomány nagysága, mind a tőelőfordulások száma szinte ugyanolyan arányban különbözik a lemmákétól, ahogyan az első magyar sakk-könyvben (vö. HoRVÁTH 2010: 427, 429-430). Ebből a megfigyelésből kiindulva olyan lehetőség adódik, amelyet itt és most csak felvetésként merek és akarok megfogalmazni: a jövőben talán érdemes volna „becslési mutatót” keresni az állomány nagyságára, illetve az előfordulási számra nézve a szavak, a lemmák és a tövek közötti összefüggésekben.

A Toldi tőállománya 1147 tagú, összesen 11707 előfordulá s sal. Egy-egy tőre tehát átlagban 10,21 előfordulás jut. 
Az eredetkategóriák képviseletét az 1 . tá b lá z a mutatja be.

\section{1. táblázat}

A Toldi I. típusú tőeredet-statisztikája

\begin{tabular}{|l|r|r|r|r|}
\hline Eredet & \multicolumn{1}{|c|}{ Tö } & \multicolumn{1}{c|}{$\mathbf{c}$} & Elöfordulás & \% \\
\hline uráli & 77 & 6,71 & 3446 & 29,44 \\
\hline finnugor & 154 & 13,43 & 2475 & 21,14 \\
\hline ugor & 79 & 6,89 & 648 & 5,54 \\
\hline tisztázatlan rétegböl & 38 & 3,31 & 1073 & 9,17 \\
\hline örökség összesen & $\mathbf{3 4 8}$ & $\mathbf{3 0 , 3 4}$ & $\mathbf{7 6 4 2}$ & $\mathbf{6 5 , 2 8}$ \\
\hline onomatopoetikus & $\mathbf{1 1 9}$ & $\mathbf{1 0 , 3 7}$ & $\mathbf{4 4 5}$ & $\mathbf{3 , 8 0}$ \\
\hline permi & 2 & 0,17 & 8 & 0,07 \\
\hline iráni & 11 & 0,96 & 65 & 0,56 \\
\hline török & 85 & 7,41 & 419 & 3,58 \\
\hline német & 38 & 3,31 & 84 & 0,72 \\
\hline latin & 18 & 1,57 & 36 & 0,31 \\
\hline olasz & 17 & 1,48 & 31 & 0,26 \\
\hline román & 1 & 0,09 & 2 & 0,02 \\
\hline szláv & 124 & 10,81 & 502 & 4,29 \\
\hline tisztázatlan nyelvből & 5 & 0,44 & 14 & 0,12 \\
\hline közvetített & 7 & 0,61 & 11 & 0,09 \\
\hline vándor & 12 & 1,05 & 27 & 0,23 \\
\hline jövevény összesen & $\mathbf{3 2 0}$ & $\mathbf{2 7 , 9 0}$ & $\mathbf{1 1 9 9}$ & $\mathbf{1 0 , 2 4}$ \\
\hline bizonytalan & 132 & 11,51 & 1311 & 11,20 \\
\hline vitatott & 47 & 4,10 & 235 & 2,01 \\
\hline ismeretlen & 181 & 15,78 & 875 & 7,47 \\
\hline tisztázatlan összesen & $\mathbf{3 6 0}$ & $\mathbf{3 1 , 3 9}$ & $\mathbf{2 4 2 1}$ & $\mathbf{2 0 , 6 8}$ \\
\hline Összesen & $\mathbf{1 1 4 7}$ & & $\mathbf{1 1 7 0 7}$ & \\
\hline & & & & \\
\hline
\end{tabular}

A következőkben az összkép jellemzésében és a részleteket taglalva természetesen többször hivatkozom a régebbi tőeredet-statisztikáimra, valamint a Toldi lemmastatisztikájára. A lapszámos utalás folytonos ismétlésének megelőzésére itt adom meg az I. típusú (azaz a bizonytalanság és a vitatottság kategóriáit szerepeltető) táblázatok lelőhelyeit: a 20. század végi elbeszélésekből összeállított korpuszom tőstatisztikája: HORVÁTH 2000: 326; az első (a 18. századból való) magyar sakk-könyv tőstatisztikája: HORVÁTH 2010: 430; a Toldi lemmastatisztikája: HoRVÁTH 2017: 462-463.

A Toldi tőállomán ya a fókategóriák reprezentáltságának sorrendjét illetően meglepetéssel szolgál: a tisztázatlan eredetüek képviselete a legnagyobb benne, az állomány tagjainak csaknem a harmada közéjük tartozik. Maga a tekintélyes részesedés viszont nem meglepő: ezt megközelítőt találtam a 20. század végi 
elbeszélésekből összeállított szövegmintámban és az első magyar sakk-könyvben is. Az eredmény mindenesetre látványos jele annak, mennyivel több a nehézség, a tisztázatlanság a tövek etimologizálásában, mint a lemmákéban, a lemmaállományban ugyanis a tisztázatlan eredetüek részesedése mindössze $8 \%$-nyi.

A tisztázatlan eredetü tövek állományának a fele ismeretlen származású. Ez a Toldi teljes tỏállományából 16\%-os részesedést jelent. Szintén $10 \%$ feletti a bizonytalan eredetüek képviselete. A vitatott eredetűeké ennél jóval kisebb: az $5 \%$-ot sem éri el.

A tőállományból az alapnyelvi örökség is 30\%-nál nagyobb arányban részesedik. Képviselete azonban meglepő mértékben kisebb a 20. század végi elbeszélésekben és a 18. századi sakk-könyvben látottnál, azokban ugyanis megközelítette a 40 , illetve az 50\%-ot.

Az alapnyelvi rétegek közül a kiemelkedő vezető szerep - a másik két említett korpusz tỏállományához hasonlóan - a finnugoré.

A jövevények fökategóriájának képviselete sem sokkal marad el a 30\%-tól. Részesedésük nagyobb a 20. század végi elbeszélésekben mértnél, az első sakkkönyvbelinél pedig különösen.

Régebbi felméréseim eredményei alapján és a lemmastatisztika ismeretében biztosan lehetett számítani arra, hogy a jövevénytövek közül szláv eredetüből van a legtöbb, őket pedig a török származásúak követik. A Toldi-beli tőállományban a szlávok a $10 \%$-os küszöböt is átlépik.

Az etimológiai statisztikákban szokásoshoz illően a fökategóriákat tekintve a Toldi lemmaállományában is a belső keletkezésüek domináltak. A „lemmák $\rightarrow$ tövek" irányú átsorolás természetéből adódóan (és persze szintén a szokásos forgatókönyv szerint) azonban ez a fökategória szinte teljesen kiürült, pontosabban az onomatopoetikus elemek őrződtek meg belőle, ezek vették át a helyét. Képviseletük a Toldi tóállományában $10 \%$-os, hasonló a szláv jövevényekéhez. Ez a részesedés az első magyar sakk-könyvben mértnek a többszöröse, a 20. század végi elbeszélésekben mértet szintén felülmúlja.

Az egyes kategóriáknak, főkategóriáknak a képviselői természetesen nagyon különböző mértékben ismétlődnek, ezért a tő e lő fordulá s o k között egészen mások az arányok, mint a tỏállományban. Mint az 1. táblázat előtt említettem, a Toldiban egy-egy tőre átlagban 10,21 előfordulás jut. Ezzel az ismétlődési hányadossal vethetö össze a táblázat segítségével az egyes főkategóriáké: örökség: 21,96; onomatopoetikus elemek: 3,74; jövevények: 3,75; tisztázatlan eredetüek: 6,73. Az alapnyelvi rétegekből örökölt töveknek az ismétlődése tehát az átlagnak a dupláját is meghaladja, míg a másik három főkategória ezzel összefüggésben elmarad az átlagtól.

A fökategóriákra nézve látványos az alapnyelvi örökség térhódítása. Képviselete itt a kétharmadosat is megközelíti. Igaz, a sakk-könyvbeli arányt nem éri el.

Az örökség térnyerése miatt a többi fökategória részesedése persze csökken. A tisztázatlan eredetűeké még így is tekintélyes: $20 \%$ feletti. A jövevényeké feleakkora. Az onomatopoetikus elemeké $4 \%$ alá kerül. Régebbi vizsgálataim anyagában ezekhez nagyjából hasonló arányokat találtam. Csupán az onomatopoetikus elemeknek a sakk-könyvbeli igen kevés előfordulása „lóg ki” a képből, de a szövegtípus tulajdonságai, szaknyelvi jellege miatt ez nem meglepő. 
Az alapnyelvi ö r ö k s é g rétegeiből a tőelőfordulások között az uráli dominál. Míg az állományban a képviselőinek száma csak a fele a finnugorokénak, sőt valamicskével még az ugorokétól is elmarad, az összes előfordulást tekintve az uráliak kerülnek a kategóriák listájának élére: részesedésük önmagában is megközelíti a 30\%-ot. Ez nem is csoda, hiszen akadnak olyan képviselőik, amelyekből sok lemma származik, köztük igen gyakoriak is. Példaként talán elég a leggyakoribb tőnek, az a névmástőnek az esetét említenem. Önálló mutató névmási lemmaként csupán kétszer jelenik meg a Toldiban. Töként viszont nagyon sok névmásnak, névmási határozószónak az alapja vagy összetevője, és ezek között gyakoriak is vannak: az úgy (47 lemmaadattal) és az ott (25-tel), valamint az aki (22-vel). De a legfontosabbat még nem is említettem: a szófajváltással keletkezett $a$ névelö, a lemmák közül a leggyakoribb is az $a$ névmástőre megy vissza a maga 666 (!) adatával.

A Toldi uráli származású tövei közül, mint a példa elárulta, az $a$ névmástő a leggyakoribb 877 adattal. A listán palatális párja, az $e$ követi, szintén magasan kiemelkedve a tövek sorából (719 adattal; magának az $e$ mutató névmásnak a 24 előfordulásán kívül ezekkel: is 131, és 89, egy névelö 59, sem 54, így 35, egy számnév 32, én $28 \mathrm{stb}$.). Százas nagyságrendủ adat tartozik még a mi kérdő névmási tőhöz (381; magának a névmásnak a 20 adatán kívül ezek: mint kötőszó 46, mert 31, mintha 28, minden 26, mely 21, mikor 21 stb.), a ho- névmástőhöz (315; benne: hogy kötöszó 94, ha 54, mintha 28, hanem 24, hogy 'hogyan, ahogy' 24 stb.), továbbá a föl-höz (110; egyebek mellett minden megjelenő fel igekötős igével). Ötven feletti még a megy (63) és a lát igéhez (51), továbbá a fél névszóhoz (51) összegyülő előfordulások száma is.

A finnugor rétegből örökölt tövek részesedése az összes előfordulást tekintve kisebb az uráliakénál, de szintén $20 \%$ feletti. A legtöbbször előforduló képviselőjük a nem tagadószó, amelyhez számos összetett lemmától is gyülnek adatok, noha kevés olyantól, amely gyakorinak mondható (összesen 343 adat; magának a tagadószónak a 181 előfordulásán kívül idetartoznak: sem 54, hanem $24 \mathrm{stb}$.). A finnugor eredetü tövek előfordulási listájának a második helyén az az elem áll, amelyet azonosító címkeként az EWUng. mög címszavával nevezek meg (228 tőelőfordulás; idetartoznak a meg igekötős igék, továbbá: még 29, meg kötőszó 12 stb.). Kétszáz feletti a van-hoz sorolhatók adatszáma is (206; van $151+$ vagy kötőszó 25 , valami 6 stb.). Százas nagyságrendben fordul még elő a má- tỏ (149; benne: most 40, már 24, majd 22, más 13, ma 11, másik 11 stb.). Ötvennél több tóadat képviseli a bél (65) és a mag (58) fönevet, valamint a lesz igét (61) és a ne tiltószót (53).

Az ugor korból örökölt tövek állománya kissé nagyobb az uráliakénál. Az ismétlődés azonban sokkal kevésbé jellemző rájuk, mint uráli és finnugor társaikra, tehát az előfordulásokra nézve messze elmaradnak tőlük. Leggyakoribb képviselőik közül is csak kettőnek van ötvennél több adata: a kiv-nek nevezhetőnek (89; a ki igekötős igék, valamint néhány határozószó) és a jó-nak (68; jó 34 + jól 5, jobban 3 stb., ill. igaz 1, jog 1 stb.).

Az alapnyelvböl örökölt tövek között akadnak olyanok, amelyekkel kapcsolatban nincs tisztázva, hogy melyik rétegből valók. A Toldiban állományuk 
az ugorokénak a felénél is kisebb, sürü ismétlödésüknek köszönhetően azonban az előfordulásokra nézve bőven megelőzik amazokat. Rendkívül gyakran megjelenő képviselöik is vannak: az (368; az mutató névmás $105+a z$ névelő 157, azután 24, akkor 20, azért 12 stb.) és az el (206; az el igekötős igék és származékaik, valamint néhány határozószó és névutó). Ötvennél több adat képviseli még a $k i$ névmást (87; ki $50+$ aki 22, senki 11, akárki 2, valaki 2), az ez mutató névmást (64; ez névmás $43+$ ennyi 4, ekképp 3 , ezalatt 3 stb.) és az út fönevet (56; út $13+$ azután 24 , utána $5 \mathrm{stb}$.). Az az és ez esetében a rétegbeli vitatottság oka az, hogy nincs tisztázva, mikor csatlakozott a -z névmásképző a tőhöz (a részleteket 1 . az EWUng.-ban; a tőstatisztikai besoroláshoz vö. még HoRVÁTH 2002: 275). Szeretném itt elörebocsátani, hogy a tisztázatlan rétegből örökölt tövek leggyakoribb képviselőinek nagy része a II. típusú statisztikában a finnugor réteghez került át, és ez persze nagyban hozzájárult a finnugor tövek ottani térnyeréséhez.

A főkkategóriák között a belső keletkezésủek helyébe lépő o n o m a t o p o e t i k u s elemek ismétlődési hányadosa sokkal kisebb az átlagosnál. Érthető tehát, hogy előfordulási részesedésük jóval elmarad az állománybelitől. Kiemelkedően leggyakoribb képviselőjük a de kötőszónak az előzményéül szolgáló de partikula (84; de kötöszó $75+$ dehogy 6 , dejszen 1, nemde 1, nemdenem 1). Utána a jaj következik (24; jaj $21+$ eljajdul 1, jaj-keserves 1, jajszó 1). A hangutánzó igetövek közül a sír jelenik meg legtöbbször (16; sir $9+$ sirat 3, sírás 2, sirály 1, sír-rí 1).

A jö v e vé n y e k ismétlődési hányadosa ugyanolyan kicsi, mint az onomatopoetikus töveké. A jövevénytövek közül, akárcsak az állományban, az előfordulásokat tekintve is szláv eredetüből van a legtöbb, öket pedig a törökök követik. Ezen a két kategórián kívül másnak itt nincs is 1\%-nál nagyobb képviselete.

A szláv jövevények közül egynek az előfordulási száma sem éri el az ötvenet, a húszat viszont haté is: király (48; király $41+$ királyi 4, királyfi 1, királyudvar 1 , kiskirály 1$)$, vitéz (30; vitéz 26 + vitézség 2 , vitézi 1 , vitézlö 1$)$, cseh (26), dolog (23; dolog $22+$ dolgozik 1), szolga (23; szolga $21+$ szolgál 1, szolganép 1$)$, beszéd (22; beszéd $10+$ beszél 8, elbeszél 4).

A török származásúak közül négynek van húsznál több adata: kép (32; kép $10+$ képzel 4, miképp 4, ekképp 3 stb.), erö (31; erö $14+$ erös 13 , erösit 1 , eröskegyetlenül 1 , erösség 1 , erötlen 1$)$, bú (22; bú $5+$ bús 5 , búsul $3 \mathrm{stb}$.), idö (21; idö 7 + midön 9, amidön 2, esztendö 2, koránsem 1 [vö. EWUng. korán ${ }^{2}$ a.]).

A többi jövevénykategóriában nincs olyan tő, amelynek az előfordulási száma húsz feletti.

A kategóriák gyakorisági listáján a török elemeket a németek követik. A leggyakoribb képviselőik: marha (9; marha 7 + aprómarhanyáj 1, marhavásár 1), kanna (6), pár (6), pint (6; pint $3+$ pintes 2, ötpintes 1$)$, tarsoly (6), tenyér (6; tenyér $5+$ tenyérnyi 1$)$.

Iráni elemből a Toldi tỏállományában nincs sok, de a jövevények közül ennek a kategóriának a legnagyobb az ismétlődési hányadosa. A legtöbbször megjelenő reprezentánsa az asszony (14; asszony 10 + anyámasszony 2, özvegyasszony 2). Érdekes a tíz esete: önálló lemmaként nincs meg a Toldiban, viszont tőként annyi adatot gyüjt magához, hogy az a második leggyakoribb iráni elemmé avatja (12; 
tizedik 3, tizenkét 3, kilenc-tíz 1, tizedel 1, tizenegyedik 1, tizenkettedik 1, tí-tizenkét 1 , de az utóbbi a tỏ kétszeres jelenléte miatt 2 tőadatként kerül a statisztikába).

A latin és az olasz jövevények a tóállományt tekintve az irániak előtt állnak, sokkal ritkább ismétlődésük miatt azonban az előfordulásokra nézve jóval elmaradnak tőlük.

A latin jövevények közül a mód tủnik fel legtöbbször ( 7 ; mód $6+$ módnélküli 1). Utána ezek következnek: cifra (4), cimbalom (4; cimbalom $2+$ cimbalmos 2 ).

Az olaszok között ezeknek van kettőnél több adatuk: part (5), pajzs (3), rest ( 3 ; rest $1+$ restell 2$)$, vendég $(3$; vendég $2+$ vendégoldal 1$)$.

A Toldi tőállományában két permi jövevény van jelen. A gyakoribb a lemmaként is meglévő kenyér (6). Az ezüst újdonság a lemmakészlethez képest (2; ezüstkoszorú 1 , ezüstös 1$)$.

Akárcsak a lemmaállományban, a tövekében is az egyetlen román elem a cimbora (2 adattal).

Egyes jövevényekkel kapcsolatban nincs tisztázva, melyik az a nyelv, amelyből a magyarba kerülhettek. Ennek a csoportnak az egynél többször felbukkanó reprezentánsai: bér (6; bér $1+$ béres 5), köntös (3), rúd (3).

Szintén akadnak olyan jövevények, amelyek nemcsak egy nyelvből jutottak el a magyarba, hanem talán egy másiknak a közvetítésével is. Az ilyeneket (akárcsak szó- és lemmastatisztikámban) az átadó nyelvektől függetlenül a „közvetített” elnevezésü jövevénykategóriába vontam össze. Egynél többször megjelenő képviselőik: az olaszból talán latin közvetítéssel is átvett tréfa $(3$; tréfa $2+$ tréfaság 1), valamint a latinból esetleg szláv közvetítéssel is átkerült alamizsna (2) és pogány (2).

A vándorszók is a (tágabb értelemben vett) jövevények fökategóriájába sorolhatók. Képviselöik a tóállományban az irániakhoz hasonló számban vannak jelen, de sokkal ritkábban ismétlődnek azoknál. Közülük ezek a leggyakoribbak: paripa (5), levente (4), szoba (4; szoba 3 + hálószoba 1), tarisznya (4).

A tisztázatlan e redetủek főkategóriájában a bizonytalan származású tövek ismétlődési hányadosa lényegében megfelel a Toldi egész tőanyagára érvényes átlagnak, a vitatott és az ismeretlen eredetűeké ellenben messze elmarad attól. Emiatt a bizonytalan eredetủek részesedése nagyjából akkora az előfordulások között, mint az állományban, míg a vitatott és az ismeretlen származásúaké az állományinak a felét sem éri el.

A bizonytalan és a vitatott eredetü tövek leggyakoribb képviselőiről úgy szólok, hogy a II. típusú (azaz a bizonytalanság és a vitatottság kategóriáit felszámoló) statisztikában érvényes minősítésüket is jelzem.

A bizonytalan eredetűek négy leggyakoribb képviselőjének a finnugor származtatása jöhet szóba. Ez a II. típusú statisztikában természetesen jelentős nyereség ennek az alapnyelvi rétegnek.

A lista elején óriási fölénnyel és hatalmas adatszámmal a $s$ áll $(513 ; s 132+$ is 131, és 89, sem 54, nincs 18, se 12, sincs 10 stb.; megjegyzés: a sincs a s elemet kétszeresen tartalmazza, tehát az adatszám valójában 10 helyett 20). Majdnem százszor fordul elő a nagy (98; nagy 85 + nagyon 9, nagyapa 1, nagyfejü 1, nagy- 
le 1, nagyúri 1). Utána a le következik (49; a le igekötős igék tartoznak hozzá, valamint az imént említett nagy-le). A negyedik pedig a vég (38; vég $10+$ végre 13 és sok más egy-két adattal).

A bizonytalan eredetüek olyan képviselőiböl, amelyekre nézve nem a finnugor származás vehető számításba, a talán törökből átvett ér igének van a legtöbb adata (29; ér ige $5+$ érez 5 , ért 5, továbbá kisebb adatszámú származékok és igekötős összetételek).

A bizonytalan származású tövek között persze olyanok is akadnak, amelyek talán onomatopoetikus eredetüek. Közülük háromnak van kettőnél több adata; mindhárom tö fiktív: csill- (3; csillapul 3), kár- (3; káromkodás 1, káromkodik 1, káromol 1$)$, sim- (3; simogat 2 , végigsimogat 1$)$.

Meglepőnek tünhet, de olyan bizonytalan eredetü tövek is vannak, amelyek a II. típusú statisztikában az ismeretlen származásúakhoz kerülnek. Ez akkor történhet meg, ha az EWUng. a „bizonytalan eredetü, talán származékszó fiktív tőből" minősítést használja, a fiktív tövet pedig ismeretlen eredetünek tartja. Az efféle tövekből a Toldiban az ism- a leggyakoribb (7; ismer 3, megismer 2, ismeretlen 1 , kiösmerszik 1$)$.

A vitatott eredetü tövekből az n-nel címkézhető a leggyakoribb. Ez az én személyes névmás utótagja (34; én 28 + engem 3 , énrám 1 , énrólam 1 , enyém 1$)$. Többféle származtatása közül leginkább az uráli névmási eredet jön számításba.

A gyakorisági listán szorosan követi az úr (31; úr 14 + ország 7, úri 3, bátyádurad 1, nagyúri 1, országút 1 , teremburádat 1 , úradta 1 , uramfia 1 , úrmaga 1); ennek a török eredeztetése a valószínűbb. Az utána következő ör- tőnek pedig a finnugor (25; öröm 12, örül 9, megörvend 1, örömest 1 , örömkönnyü 1 , örömzaj 1).

Az olyan vitatott eredetü tövek közül, amelyeknek az onomatopoetikus magyarázatuk a meggyőzőbb, a báty- fordul elő legtöbbször (16; bátya 14, bátyádurad 1 , testvérbátya 1$)$.

Egyszer még az a különleges helyzet is előáll, hogy a „vitatott” minősítést a II. típusú tőstatisztika számára „ismeretlen”-re kell cserélni; a részletekhez 1 . az EWUng. üld szócikkét (a visszavezetett lemma az üldözö, 1 adattal).

A tisztázatlan származásúak harmadik csoportjából, az ismeretlen eredetü tövek közül gyakoriságával magasan kiemelkedik a csak (74; csak 61 + ugyancsak 4, csakhamar 3, csakhogy 2, csakúgy 2, csaknem 1, nemcsak 1). Rajta kívül sok adata van még a ked- tőnek is; ez a pedig-et és körét vonja magához (47; pedig 43, pediglen 2, éspedig 1, mégpedig 1).

Az I. típusú tőeredet-statisztika lezárásaként itt mutatom be a Toldi le ggyakoribb töveinek összegzett listáját. A kategóriák szemléjében közölt részleteket, magyarázatokat nem ismétlem meg, de zárójelben megadom az eredetminősítéseket, szükség esetén (kettősponttal bevezetve) megtoldva őket a II. típusú statisztikában érvényessel: 1. a 877 (uráli) | 2. e 719 (uráli) | 3. $s 513$ (bizonytalan: finnugor) |4. mi (kérdö) névmás 381 (uráli) |5. az 368 (tisztázatlan rétegü örökség: finnugor) |6. nem tagadószó 343 (finnugor) |7. ho- 315 (uráli) | 8. mög 228 (finnugor) |9-10. el 206 (tisztázatlan rétegü örökség: finnugor); van 206 
(finnugor) | 11. má- 149 (finnugor) | 12. föl 110 (uráli) | 13. nagy 98 (bizonytalan: finnugor) | 14. kiv 89 (ugor) | 15. ki névmás 87 (tisztázatlan rétegü örökség: finnugor) $\mid$ 16. de partikula 84 (onomatopoetikus) |17. csak 74 (ismeretlen) |18. jó 68 (ugor) | 19. bél 65 (finnugor) | 20. ez 64 (tisztázatlan rétegü örökség: finnugor) $\mid 21$. megy 63 (uráli) | 22. lesz 61 (finnugor) $\mid 23$. mag 58 (finnugor) $\mid 24$. út 56 (tisztázatlan rétegü örökség: finnugor) $\mid 25$. ne tiltószó 53 (finnugor) |26-27. fél névszó 51 (uráli); lát 51 (uráli). Önmagáért beszél, hogy ennek a listának 23 (!) eleme az alapnyelvi örökséghez tartozik. Ráadásul a két jelenlévő bizonytalan származású tő is talán örökség. Az onomatopoetikus és az ismeretlen eredetű töveknek egy-egy reprezentánsuk szerepel a listában, a jövevényeknek egy sem.

A II. típusú tőeredet-statisztika képét a 2. táblázat rögzíti.

2. táblázat

A Toldi II. típusú tőeredet-statisztikája

\begin{tabular}{|l|r|r|r|r|}
\hline Eredet & \multicolumn{1}{|c|}{ Tö } & \multicolumn{1}{c|}{$\mathbf{~ \%}$} & Elöfordulás & \multicolumn{1}{c|}{$\%$} \\
\hline uráli & 108 & 9,42 & 3634 & 31,04 \\
\hline finnugor & 225 & 19,62 & 4300 & 36,73 \\
\hline ugor & 114 & 9,94 & 908 & 7,76 \\
\hline orrökség összesen & $\mathbf{4 4 7}$ & $\mathbf{3 8 , 9 7}$ & $\mathbf{8 8 4 2}$ & $\mathbf{7 5 , 5 3}$ \\
\hline onomatopoetikus & $\mathbf{1 4 0}$ & $\mathbf{1 2 , 2 1}$ & $\mathbf{4 9 1}$ & $\mathbf{4 , 1 9}$ \\
\hline permi & 3 & 0,26 & 9 & 0,08 \\
\hline iráni & 19 & 1,66 & 115 & 0,98 \\
\hline kaukázusi & 1 & 0,09 & 2 & 0,02 \\
\hline török & 109 & 9,50 & 591 & 5,05 \\
\hline német & 46 & 4,01 & 110 & 0,94 \\
\hline latin & 22 & 1,92 & 43 & 0,37 \\
\hline francia & 1 & 0,09 & 1 & 0,01 \\
\hline olasz & 19 & 1,66 & 41 & 0,35 \\
\hline román & 1 & 0,09 & 2 & 0,02 \\
\hline szláv & 128 & 11,16 & 522 & 4,46 \\
\hline tisztázatlan nyelvböl & 1 & 0,09 & 1 & 0,01 \\
\hline közvetített & 1 & 0,09 & 1 & 0,01 \\
\hline vándor & 13 & 1,13 & 28 & 0,24 \\
\hline jövevény összesen & $\mathbf{3 6 4}$ & $\mathbf{3 1 , 7 3}$ & $\mathbf{1 4 6 6}$ & $\mathbf{1 2 , 5 2}$ \\
\hline ismeretlen & $\mathbf{1 9 6}$ & $\mathbf{1 7 , 0 9}$ & $\mathbf{9 0 8}$ & $\mathbf{7 , 7 6}$ \\
\hline Összesen & $\mathbf{1 1 4 7}$ & & $\mathbf{1 1 7 0 7}$ & \\
\hline
\end{tabular}

Ez a kép az I. típusú statisztikának a 2. pontban ismertetett elvek szerint való átrendezésével alakult ki. A bizonytalanok és a vitatottak kategóriájának megszünésével a tisztázatlanok főkategóriája az ismeretlen eredetủekének adta 
át a helyét. Az átsorolás az alapnyelvi örökség tisztázatlan rétegét is felszámolta. Nem tủnt el viszont teljesen a tisztázatlan nyelvből származó jövevények kategóriája, mivel egy képviselője ismeretlen nyelvből való: ez a bükk.

Nem lett egészen üres a közvetítéssel átvett jövevények kategóriája sem: megmaradt benne az oszmán-törökből valószínüleg szerbhorvát közvetítéssel átkerült korbács. A többi olyan jövevény azonban, amely az I. statisztikában még ehhez a kategóriához tartozott, átkerült a „„o"” átadó nyelv reprezentánsaihoz, mivel közvetített voltuk az EWUng. szerint csak esetleges lehetőségként vetődik fel.

A bizonytalan és a vitatott eredeztetések felszámolása más irányú következménnyel, új jövevénykategóriák megjelenésével is járt. Az egyik a kaukázusi: képviselője az I. statisztikában a bizonytalan származásúak közé tartozó réz (2 adattal). A másik pedig a francia: képviselője, a kilincs az I.-ben a vitatottaknál szerepel.

Az I. és a II. statisztika közötti átrendezéssel minden megmaradó főkategória részesedése nő. Az igazi nyertesnek azonban az alapnyelvi örökség főkategóriája tekinthető: az állományban 8 , az előfordulások között pedig 10 százalékponttal gyarapszik a képviselete. Az utóbbi azt jelenti, hogy a Toldi tőelőfordulásainak a háromnegyede az alapnyelvi örökséghez tartozik.

Ahogy az I. tőstatisztika elemzésének néhány részlete alapján feltételezhető volt, elsősorban a finnugor réteg térnyerése szembetünő: mind az állományban, mind az előfordulásokat tekintve mindegyik kategóriáét megelőzi a részesedése.

4. Összegzés és kitekintés. A tőeredet-statisztika két változatának elkészítésével és bemutatásával teljessé vált a Toldi etimológiai statisztikája. Az első magyar sakk-könyv anyagának a vizsgálata után (vö. HORVÁTH 2010) ez a második olyan gyakorisági felmérésem, amelyet nem szövegrészletek vagy rövid nyelvemlékek, hanem terjedelmes és egész mú alapján végeztem a szavakra, a lemmákra és a tövekre is kiterjedve, beleértve állományukat és előfordulásaikat.

Bízom abban, hogy ez a két felmérés, különösen a Toldié, összehasonlítási alapul szolgálhat más hasonlókhoz: mind az elveket és a módszereket, mind pedig a konkrét, számszerü eredményeket tekintve.

Úgy vélem, a Toldi etimológiai statisztikája az oktatásban is hasznosítható, persze az adott szint lehetőségeihez, igényeihez illő válogatással.

Természetesen a Toldi tőeredet-statisztikájának elkészülte sem jelenti azt, hogy az etimológiai kategóriákra nézve a müvel kapcsolatban nem maradtak nyitott, kutatásra érdemes kérdések. Példaként most csak kettőt említek közülük. Meg kellene vizsgálni, miért kisebb a Toldiban a belső keletkezésü lemmák részesedése, mint amilyenre más felméréseim alapján számíthattam (vö. HoRVÁTH 2017: 464). Érdekes lenne továbbá annak a feltárása is, mekkora a müben az alapnyelvi örökség részesedése akkor, ha a körét a fogalomszói elemekre korlátozzuk.

Kulcsszók: Toldi, etimológiai statisztika, a tövek eredetstatisztikája, állományi statisztika, előfordulási statisztika. 


\section{Hivatkozott irodalom}

EWUng. = Etymologisches Wörterbuch des Ungarischen 1-2. Hrsg. BENKÖ, LORÁND. Akadémiai Kiadó, Budapest, 1993-1995. + Register. Akadémiai Kiadó, Budapest, 1997.

HoRVÁTH LÁSZLó 2000. Etimológiai kategóriák arányai mai elbeszélésekben. Magyar Nyelv 96: 170-181, 316-332.

HoRVÁTH LÁsZló 2002. Az Ómagyar Mária-siralom etimológiai statisztikája. Magyar Nyelv 98: 265-282.

HoRVÁTH LÁSzLó 2010. Az első magyar sakk-könyv etimológiai statisztikája. Magyar Nyelvör 134: 421-436.

HoRVÁTH LÁSZLó 2017. A Toldi szókészletének eredetéről. Magyar Nyelv 113: 450-466. https://doi.org/10.18349/MagyarNyelv.2017.4.450

ToldiSz. = PÁszTOR EMIL, Toldi-szótár. Arany János Toldijának szókészlete. Tankönyvkiadó, Budapest, 1986.

\section{On the origin of the stems in Arany's Toldi}

The author has been working on etymological statistics for more than twenty years now. In 2017, he compiled a statistics of origin of the most widely known Hungarian epic poem, János Arany's Toldi, with respect to the inventory and occurrence (types and tokens) of the words and lemmas occurring in it. The present paper is a counterpart of the 2017 paper, complementing it in some respects. This time, the author explores the proportions of categories of origin with respect to the stems of the words included in the poem. On the one hand, the results are compared to those of the earlier study, and on the other hand, the present paper is intended to serve as a basis of comparison for similar studies in the future. The author hopes that the results of his analyses can be utilised at various levels of education from primary schools to doctoral studies.

Keywords: Toldi, etymological statistics, statistics of origin of stems, inventory statistics, occurrence statistics.

HORVÁTH LÁSZLÓ

Nyelvtudományi Intézet 